\title{
Auto-retrato, de João Melo: reflexos de um poeta afinado com o seu tempo
}

\author{
Érica Antunes Pereira ${ }^{1}$ \\ Universidade de São Paulo
}

rimeira das cinco antologias poéticas de João Melo que serão editadas pela Editorial Caminho, Auto-retrato, publicada em 2007, reúne 44 poemas e fragmentos de prosa voltados, como prenuncia o título, para uma linha lírico-intimista caracterizada pelo vínculo com a memória, a infância, os laços familiares e o cotidiano. Mas não é só: a tais elementos agrega-se a preocupação com o fazer literário, como no poema "Duas lições":

Todos os materiais servem ao poeta:

o som de um tambor,

a angústia de uma mulher nua,

a lembrança de uma utopia.

A vida deposita, diariamente,

no altar profano da poesia,

a sua dádiva generosa:

estrelas e detritos.

E tudo a poesia sacrifica. (p. 10)

O "procedimento da metalinguagem" é tão marcante e reiterado que, conforme afirma Tania Macêdo no posfácio à obra, "chega a constituir um tema" e faz de Auto-retrato "uma galeria de retratos poéticos que compõem a paisagem da unidade do fazer artístico do escritor" (p. 76).

\footnotetext{
1 Doutoranda em Estudos Comparados de Literaturas de Língua Portuguesa na Universidade de São Paulo (USP) e bolsista da Fundação de Amparo à Pesquisa do Estado de São Paulo (FAPESP).
} 
Os verbos, na maioria dos poemas, são empregados no presente do indicativo, traduzindo uma espécie de perenidade que pode se tornar paradoxal se, concomitantemente, for abordado, por exemplo, o tema da finitude da vida humana, caso do poema "A minha avó Merceana":

A minha avó Merceana pensa ter vivido o bastante, mas a vida mesmo acha que não.

Todas as noites talvez ela tenha desejos suicidas, grandiosos ou sombrios, mas é implacável o tempo que a sustém.

Quão lenta é a morte! - deve ela exasperar-se.

Nós, que a amamos como se ama

a própria carne, não gostamos de saber que um dia ela nos deixará.

Mas é implacável o tempo que celeremente a está levando... (p. 62)

Outra recorrência é o uso dos dois-pontos, uma estratégia para transitar entre a exposição e a definição do eu poético - que, algumas vezes, esbarra propositalmente na biografia do autor - e/ou de situações, reafirmando, mais uma vez, o título da obra. É o que notamos em "Os tambores anunciam a caçada":

Aqui estou eu: trinta e quatro anos

um pai-mito, um irmão-soldado,

duas filhas e certas mulheres

por quem ainda espero.

$[\ldots]$

Eis as minhas armas:

azagaias de memória, uns poemas tacteando no escuro. (p. 60)

Em Auto-retrato, o silêncio dialoga com a capacidade de observação e dá passagem tanto para a epifania quanto para a intertextualidade, o que vemos em poemas como "A minha casa" e "Penélope no trem": 
Eu entro e saio todos os dias da minha casa, mas só a vejo em dias como hoje, quando ela está vazia e silenciosa. (p. 32)

No trem entre Queluz e Lisboa uma mulher tricota. A malha ou os seus pensamentos? Uma sombra opaca reluz no seu olhar absorto.

$[\ldots]$

(E em casa não a espera Ulisses, mas José.) (p. 68-69)

Os espaços apresentados na coletânea normalmente refletem o aconchego familiar, mas também podem sinalizar o novo, fato que verificamos, por exemplo, no poema "Os livros":

Não conhecemos estes lugares

ou compulsivamente

os revemos. Paisagens

inusitadas, absurdas, mesmo se alguma vez as frequentámos com nossos olhos e bagagens. (p. 33)

Essa proposta de inovar confirma a pertença de João Melo à chamada "Geração de 1980", que, entre outras características, apresenta uma poesia mais contornada pela subjetividade e pela preocupação estética que aquela dita empenhada na luta pela construção nacional. Nessa senda, podemos afirmar que Auto-retrato reflete um sujeito poético que, em não raras ocasiões, confunde-se com o próprio poeta, e, graças à aguda lapidação da palavra, ilumina também o projeto literário que faz de João Melo um autor afinado com o seu tempo.

\section{Referência Bibliográfica}

MELO, João. Auto-retrato. Lisboa: Caminho, 2007. 